Zeitschrift für Kristallographie, Bd. 142, S. 447-449 (1975)

\title{
Comment on the structure of antimony trisulfide
}

By D. O. MCKeE and J. T. MoMULLAN

School of Physical Sciences, The New University of Ulster, Coleraine, Northern Ireland

(Received 26 March 1975)

\begin{abstract}
Auszug
Über eine Neubestimmung der Struktur von Antimontrisulfid in der paraelektrischen Phase wird berichtet; die Ergebnisse werden mit denen der früheren Bestimmung durch BAyliss und NowackI verglichen. Unterschiede in den Temperaturparametern und in der Größe der Elementarzelle werden festgestellt und darauf zurückgeführt, daß die Untersuchung in unmittelbarer Nähe des Curie-Punktes stattfand. Auf die Bedeutung der Temperaturangabe in solchen Fällen der Strukturbestimmung wird besonders hingewiesen.
\end{abstract}

\begin{abstract}
A redetermination of the structure of antimony trisulfide in its para-electric phase is reported and the results are compared with the earlier determination by Bayliss and Nowacki. Differences in the unit-cell parameters and the temperature factors are noted and are related to the close proximity of the Curie point. The importance of reporting the temperature of the structure determination in such cases is emphasized.

The crystal structure of stibnite, $\mathrm{Sb}_{2} \mathrm{~S}_{3}$, has been the object of three independent investigations, Hofmans (1933), Sóavničar (1960), Bayliss and Nowacki (1972). This last investigation was reported at a time when the authors were interested in the structure of stibnite because of its distinctive physical properties and the fact that it undergoes a first-order phase transition at $17.7^{\circ} \mathrm{C}$ (GRIGAS and Karpus, 1968a,b,c; PikKa and Fridkin, 1969). Bayliss and Nowacki (1972) did not report the temperature at which their structure data was collected, and, because of the nearness of the Curie temperature to room temperature, we felt that a redetermination under controlled conditions was necessary, particularly as our interest lay in the dynamics of the phase transition.
\end{abstract}


Very small crystals (needles $0.02 \mathrm{~mm}$ in largest width) were grown by vapour transport techniques, and the $\mathrm{x}$-ray structural investigation was undertaken using MoK$\alpha$ radiation and a Hilger and Watts automatic four-circle diffractometer. The temperature was $20^{\circ} \pm 1{ }^{\circ} \mathrm{C}$.

The structure was refined from the coordinates of SćavNIČAR (1960) using the LUXX system of crystallographic programs (LEE, 1971) by the block-diagonal least-squares method. The neutral-atom form factors were corrected for real dispersion for both $\mathrm{Sb}$ and $\mathrm{S}$, while those of $\mathrm{Sb}$ were also corrected for anomalous dispersion. The final discrepancy factor $R$ is 0.062 for 503 reflections. Reflections showing marked evidence of extinction were ignored in the final stage of refinement. Because of the extremely small size of the crystal and the use of Mo radiation, no absorption correction was necessary.

Our fractional atomic coordinates agree with those of BAYLISS and NowACKI to well within the estimated standard deviations. However the cell parameters are slightly different and this difference is significant in terms of both sets of standard deviations particularly in the value of $a$. Our cell parameters were determined automatically by the diffractometer during its preliminary orientation procedure, and were checked at regular intervals during data collection. BAYLISS and NowACkI's results were $a=11.3107(9), b=3.8363(4), c=11.2285(5)$. Ours were $a=11.3018(14), b=3.8341(6), c=11.2217(15)$. Further, the anisotropic temperature factors from the two refinements (Table 1)

Table 1. Comparison of temperature factors for stibnite

\begin{tabular}{|c|c|c|c|c|}
\hline & \multicolumn{2}{|c|}{$\beta_{11}$} & \multicolumn{2}{|c|}{$\beta_{22}$} \\
\hline $\operatorname{Sb}(1)$ & $0.0025(2)$ & $0.0023(1)$ & $0.014(2)$ & $0.025(1)$ \\
\hline $\mathrm{Sb}(2)$ & $0.0036(2)$ & $0.0032(1)$ & $0.023(2)$ & $0.032(1)$ \\
\hline$S(1)$ & $0.0027(3)$ & $0.0018(3)$ & $0.018(3)$ & $0.020(3)$ \\
\hline$S(2)$ & $0.0024(3)$ & $0.0013(3)$ & $0.018(3)$ & $0.022(3)$ \\
\hline \multirow[t]{2}{*}{$\mathrm{S}(3)$} & $0.0023(3)$ & $0.0014(3)$ & $0.027(3)$ & $0.027(4)$ \\
\hline & \multicolumn{2}{|c|}{$\beta_{33}$} & \multicolumn{2}{|c|}{$\beta_{12}$} \\
\hline $\mathrm{Sb}(1)$ & $0.0030(2)$ & $0.0023(1)$ & $0.0006(1)$ & $-0.0007(2)$ \\
\hline $\mathrm{Sb}(2)$ & $0.0027(2)$ & $0.0020(1)$ & $0.0013(1)$ & $0.0014(2)$ \\
\hline$S(1)$ & $0.0032(2)$ & $0.0015(3)$ & $0.0004(3)$ & $-0.0006(6)$ \\
\hline $\mathrm{S}(2)$ & $0.0035(2)$ & $0.0021(3)$ & $0.0008(3)$ & $-0.0004(5)$ \\
\hline $\mathrm{s}(3)$ & $0.0031(3)$ & $0.0016(3)$ & $0.0002(3)$ & $0.0001(5)$ \\
\hline
\end{tabular}

In each case the first value is from BAYLISs and NowAcki and the second value is from the present work. 
differ particularly in $\beta_{22}$ which represents displacements in the $y$ direction. These are the displacements to be associated with the ferroelectric phase transition at $17.7^{\circ} \mathrm{C}$, by analogy with the closely related compound antimony sulfur iodide SbSI (ARNDT and NigGLI, 1964). Our value of $\beta_{22}$ for each of the antimony atoms is much larger than that of BAYLiss and Nowacki, while for the sulfur atoms the differences are not so great. This is in agreement with the expected behaviour if it is assumed that our measurements were made at a slightly lower temperature, closer to the Curie point, so that the thermal oscillations of the antimony atoms were enhanced by its proximity. In SbSI, the antimony atoms are displaced by some $0.2 \AA$ in the ferro-electric transition, while the sulfur atoms are displaced by only $0.05 \AA$.

In summary we wish to confirm the overail structure determination of BAYLISS and Nowack (1972), and to suggest that the observed discrepancies between their results and ours arise through thermal effects due to the proximity of the phase transition. We feel that, because of this proximity, it is important that the temperature of the structure determination should be known.

\section{Acknowledgement}

We wish to record our appreciation to Dr. H. M. Shearer for the use of his Hilger and Watts diffractometer.

\section{References}

R. Arndt und A. Niggli (1964), Röntgenkristallographische Untersuchungen an Antimon-Sulfojodid. Naturwissenschaften 51, 158.

P. Bayliss and W. Nowacki (1972), Refinement of the crystal structure of stibnite, $\mathrm{Sb}_{2} \mathrm{~S}_{3}$. Z. Kristallogr. 135, 308-315.

A. P. Grigas and A. KarPus (1968a), Dielectric properties of $\mathrm{Sb}_{2} \mathrm{~S}_{3}$ crystals. Soviet Physics - Solid State 9, 2265.

A. P. Grigas and A. Karpus $(1968 \mathrm{~b})$, Anomalous dispersion of permittivity of $\mathrm{Sb}_{2} \mathrm{~S}_{\mathbf{3}}$ and SbSI. Soviet Physies-Solid State 9, 2270.

A. P. Grigas and A.S. Karpus (1968c), Phase transformation in the highresistance semiconductor $\mathrm{Sb}_{2} \mathrm{~S}_{3}$. Kristallografiya 12 (1967) 719--721 [in Russ.]; Soviet Physics-Crystallography 12, 627-628.

W. Hofmann (1933), Die Struktur der Minerale der Antimonitgruppe. Z. Kristallogr. 86, 225-245.

J. D. LEE (1971), Crystallographic computer programs for ICL 1900 series computers. J. Cryst. Mol. Struct. 1, 103.

T. PIKKA and V. Fridkin (1969), Calorimetric study of a phase transition in antimony sulfide. Bull. Acad. Sci. USSR 33, 335.

S. Š́́avničar (1960), The crystal structure of stibnite. A redetermination of atomic positions. Z. Kristallogr. 114, 85-97. 